\title{
A Mini-Review of Urban Wastewater Treatment in Greece: History, Development and Future Challenges
}

\author{
Charikleia Prochaska *(D) and Anastasios Zouboulis (1) \\ Laboratory of Chemical and Environmental Technology, Department of Chemistry, Aristotle University of \\ Thessaloniki, 54124 Thessaloniki, Greece; zoubouli@chem.auth.gr \\ * Correspondence: prohaska@chem.auth.gr
}

Received: 12 July 2020; Accepted: 29 July 2020; Published: 30 July 2020

\begin{abstract}
Although Greece has accomplished wastewater infrastructure construction to a large extent, as $91 \%$ of the country's population is already connected to urban wastewater treatment plants (WWTPs), many problems still need to be faced. These include the limited reuse of treated wastewater and of the surplus sludge (biosolids) produced, the relative higher energy consumption in the existing rather aged WWTPs infrastructure, and the proper management of failing or inadequately designed septic tank/soil absorption systems, still in use in several (mostly rural) areas, lacking sewerage systems. Moreover, the wastewater treatment sector should be examined in the general framework of sustainable environmental development; therefore, Greece's future challenges in this sector ought to be reconsidered. Thus, the review of Greece's urban wastewater history, even from the ancient times, up to current developments and trends, will be shortly addressed. This study also notes that the remaining challenges should be analyzed in respect to the country's specific needs (e.g., interaction with the extensive tourism sector), as well as to the European Union's relevant framework policies and to the respective international technological trends, aiming to consider the WWTPs not only as sites for the treatment/removal of pollutants to prevent environmental pollution, but also as industrial places where energy is efficiently used (or even produced), resources' content can be potentially recovered and reused (e.g., nutrients, treated water, biosolids), and environmental sustainability is being practiced overall.
\end{abstract}

Keywords: Greece; wastewater treatment plant (WWTP); history; policy; technology trends and applications

\section{Introduction}

Greece is located in the southern end of the Balkan Peninsula, bordering the Ionian, Aegean, and the Mediterranean Seas. The country has a total area of $131,940 \mathrm{~km}^{2}$ with a population of (around) 11 million, according to the last official census of 2011. Greece consists of a large mainland and extensive archipelagos of around 3000 islands, has almost $18,000 \mathrm{~km}$ of coastline and is $80 \%$ mountainous with the highest peak of $2919 \mathrm{~m}$ in Olympus [1].

The climate in Greece is predominantly classical Mediterranean (mild, wet winters and hot, dry summers). However, due to the country's geography, a range of micro-climates and local variations can be found [2]. Annual rainfall ranges from 300 to $500 \mathrm{~mm}$ in southeastern Greece and from 800 to $1200 \mathrm{~mm}$ in the northwestern parts of the mainland, but may exceed $2000 \mathrm{~mm}$ in some mountainous areas. Greece is expected to have an $18 \%$ precipitation decrease by midcentury, and $22 \%$ by the end of the century. Considering an expected modest population decline, Greece's per capita water resources are also expected to decline by midcentury [3,4]. These perspectives are likely to necessitate the implication of appropriate changes to Greece's water resources management and, consequently, changes to the respective ways urban wastewater management is commonly practiced. 
Even though Greece is among the very few ancient civilizations, where hygienic technologies and wastewater management were practiced as early as $400 \mathrm{BC}$ [5], the wastewater management history of the country has followed similar development paths as to other nations in Europe, namely Britain, France, and Germany, i.e., for centuries wastewater management was not given much, if any, attention [6]. Although in some ancient cities there were existing sewerage systems, wastewaters were usually disposed of in the streets and near the city centers, creating serious impacts on public health and the environment. The industrialization and urbanization during the second half of the 19th century shifted interest towards better wastewater management practices, while the development of the wastewater management in Greece began around the early 1980s, when the country entered the European Union (EU) and as a member state had to comply with the respective EU policies for proper urban wastewater treatment and thus, created its first urban wastewater treatment plants (WWTPs) [7].

Today, Greece's urban wastewater sector presents significant achievements, but also failures, as well as numerous future challenges. Even though the understanding of the various wastewater treatment processes is important, it is not within this paper's intentions to provide here the in-depth explanations, which can be found elsewhere. This mini-review intends to highlight the major aspects of Greece's urban wastewater treatment history, its recent developments, and present situation, as well as to identify the remaining challenges, in respect to the country's specifications, regarding the European Union's policies and the international technological trends, so as WWTPs to be seen not only as sites for the treatment/removal of pollutants, but also as "industrial" places, where energy can be efficiently used (and produced), and new products (recovery of resources' content) and business opportunities would be created.

We believe the readership of the Journal's Special Issue would be interested in this mini-review, as it highlights not only municipal wastewater management of a particular country, but addresses a country's own wastewater management path in respect to the global thinking of sustainable environmental development.

\section{The Past of Urban Wastewater Treatment in Greece}

\subsection{Historical Development}

Historical findings in palaces and cities on the island of Crete, as well as in other Aegean Islands, declare the presence of quite sophisticated sewage systems since the early Minoan civilization, which is considered as Europe's first advanced civilization, flourishing from 2700 to 1450 BC [5]. Sewage systems were found also in residencies in Delos Island (as early as $400 \mathrm{BC}$ ) and later, around $300 \mathrm{BC}$, in the ancient Pella, a city located in northern Greece, best known as the historical capital of the ancient Macedonian kingdom. However, during the same ancient times, open combined sewerage networks of wastewater and storm waters run-off were found also in several other ancient cities, causing quite frequent dispersion of serious water-borne diseases, such as cholera, plague, etc. [8].

This practice has continued for almost the next 15 centuries, before being replaced by the use of absorbing septic tanks. After saturation of the septic tank, either a new tank was built nearby, or the waste was collected and discharged untreated into open streams or into the sea. Athens, the present capital of Greece, was first declared the capital of the newly established Greek State on September 18, 1834. Six years later, the first combined flow sewerage system for the collection of both wastewaters and storm waters run-off was constructed for the first time in the modern history of Greece, noting, however, that Athens at that time was a small city with only 7000 residents.

During the years 1834-1980, the sewerage infrastructure was progressively enlarged in scale. Already in 1950, the preliminary design of the Athens Sewerage System began covering an area of around 200,000 hectares. This design was used as the basis for the development of the city's networks during the 1960s and 1970s. During the same period, similar infrastructures were built also in other large cities of Greece, e.g., in Thessaloniki (the 2nd largest city of Greece), where the first combined sewer overflow pipe was built in 1938, while the basis for the present sewerage system network was set up in 1977 [9]. 
Entering into the 1980s, the situation started to improve, as Greece joined the EU in 1981. The issue of the treatment of the collected sewage that up to this point was discharged without any treatment to nearby streams, rivers, or to the sea, started to gain particular attention.

\subsection{Development over the Past 40 Years}

As a member state of the EU, Greece had to comply with the respective EU policies for wastewater treatment. The development of urban WWTPs followed the developments of the relevant EU directives, as well as the available funding from various EU framework programs. Thus, the first modern WWTPs in Greece started their operation around the beginning of 1990s, as a consequence of the respective EU Directive 91/271/EEC [10] "on urban wastewater treatment and disposal" and its amendments, defined by the subsequent Directive 98/15/EEC [11].

The wastewater treatment plant of Thessaloniki started to fully operate in 1992. This plant is situated $7 \mathrm{~km}$ southwest of the city, currently serving about 1 million residents of the greater Metropolitan area, by treating daily around $160,000 \mathrm{~m}^{3}$ with the schedule future capacity (after extension) to be able to treat around $300,000 \mathrm{~m}^{3} /$ day. The treatment process includes screening, grid removal, primary sedimentation (without use of chemical coagulants), conventional activated sludge treatment with nitrogen removal, and effluent disinfection using chlorine gas $\left(\mathrm{Cl}_{2}\right)$. The treated effluent is mainly discharged to the nearby Thermaikos gulf, which is characterized as a sensitive area. However, some efforts of effluent reuse in irrigation were started for the first time in Greece in 1993. Approximately $2225 \mathrm{~m}^{3}$ /year of WWTP effluent is being regularly reused, after mixing with freshwater from the nearby Axios River at 1:5 ratio irrigating approximately 2500 ha of spring crops in the nearby Halastra-Kalohori agricultural area [12]. Sewage sludge (i.e., the primary plus the excess activated) is anaerobically digested, thickened, and dewatered and dried (succeeding substantial volume reduction). The greatest amount of this sludge was deposited in an urban landfill, until few years ago when this practice was prohibited, and currently, this is being commonly used as soil amendment after the appropriate control [7].

In 1994, the Psyttalia wastewater treatment plant started its operation. This unit is situated at the uninhabited island of Psyttalia, in the Saronic gulf, between the island of Salamis and the commercial port of Piraeus, approximately $13 \mathrm{~km}$ south west of Greece's capital city center (Athens) and serves approximately 4 million of population. At its current state, the wastewater treatment includes pretreatment, primary treatment, and advanced secondary biological treatment, using activated sludge processes with nitrogen removal, thermal sludge drying unit, and co-generation of electricity and heat. The sludge produced is treated anaerobically, resulting in the production of biogas. The produced biogas can cover most of the energy needs of the wastewater treatment facilities. This is one of the largest WWTPs in Europe (and internationally), with a population equivalent (p.e.) coverage of $5,600,000$ p.e. The average flowrate of incoming sewage is about 1,000,000 $\mathrm{m}^{3} /$ day. An aerial view of Phyttalia WWTP is presented in Figure 1 [13].

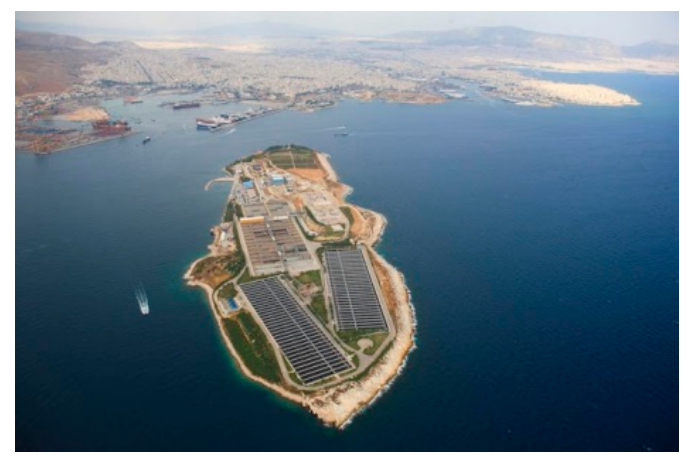

Figure 1. Phyttalia wastewater treatment plant. 
The developments of wastewater treatment in the rest of Greece had to follow the requirements and time restrictions as set by the EU Directives 91/271/EEC and 98/15/EEC. According to these, the urban wastewater entering collecting systems should have been subjected to secondary treatment or an equivalent treatment with the following timeline schedule:

1. At the latest by 31 December 1998 for urban agglomerations of more than 10,000 p.e., discharging into receiving waters, which are considered as "sensitive areas", e.g., natural freshwaters bodies; in these cases the relevant WWTPs must be complimentary designed for nitrogen and/or phosphorus removal in order to avoid eutrophication problems of the receiving water bodies.

2. At the latest by 31 December 2000 for all discharges from urban agglomerations of more than 15,000 p.e.

3. At the latest by 31 December 2005 for all discharges from agglomerations of between 10,000 and 15,000 p.e.

4. At the latest by 31 December 2005 for discharges to fresh-water and estuaries water bodies from agglomerations (settlements) between 2000 and 10,000 p.e.

The term "agglomeration" was defined in the Directives as the area where the population and/or economic activities are sufficiently concentrated for urban wastewater to be collected and conducted to a WWTP, or to a final discharge point.

The construction of sewerage networks is currently not legally enforced for agglomerations of less than 2000 p.e., unless the wastewater is discharged to sensitive water bodies. This flexibility in the application of appropriate treatment technologies shifted interest towards the operation of alternative technologies for small communities, but to a limited extent. Sequencing Batch Reactors (SBR) exist in Greece, but are not widely operated. Natural treatment systems, such Waste Stabilization Ponds (WSP) are also quite limited. The first WSP was constructed in 1982 in Sitochori village in the prefecture of Serres in northern Greece, serving a community of 1000 p.e., consisting of a primary facultative pond, followed by two maturation ponds [14]. There was a shift in preference towards the use of constructed wetlands (CWs) in the 1990s, after the operation of the first vertical flow constructed wetland (VFCW) in Nea Madytos community (3000 p.e.) of the Thessaloniki Region in north Greece, back in 1993 [15].

However, the operation of alternative technologies for the wastewater treatment of small communities has not been widely accepted as the feasible alternative to the conventional wastewater treatment systems in Greece. This can be devoted mainly because their application has not being accompanied with a parallel effort to gain wider community acceptance over the conventional wastewater treatment systems, which were already widely applied, broadly tested, and considered as more reliable solutions. Thus, out of 147 WWTPs of small communities in the year 2000, 110 were served by convenient extended aeration systems [16,17].

Figure 2 summarizes the growth of WWTPs in Greece during 1980-2015 [18], while Table 1 shows the information of some milestone WWTPs in the development history of Greece's urban wastewater sector.

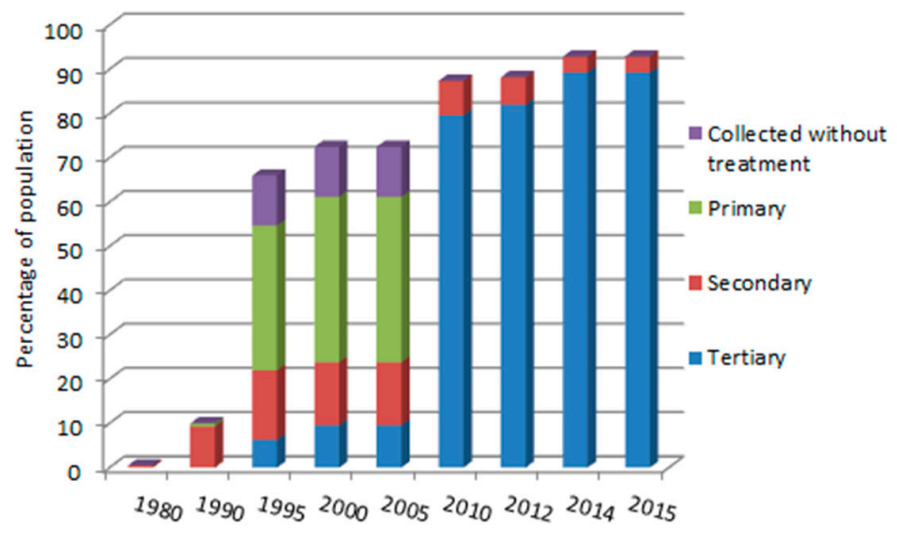

Figure 2. Growth of urban wastewater treatment plants (WWTPs) in Greece during 1980-2015. 
Table 1. Milestones of WWTPs development in Greece during 1980-2015.

\begin{tabular}{|c|c|c|c|}
\hline Year of Operation & WWTP & Capacity (p.e.) & Milestone \\
\hline 1982 & $\begin{array}{l}\text { Sitochori village (Serres } \\
\text { prefecture) }\end{array}$ & 1000 & The first WSP, serving a village community [15] \\
\hline 1992 & Thessaloniki & $1,400,000$ & The first modern large-scale WWTP in Greece [7] \\
\hline 1993 & $\begin{array}{c}\text { Nea Madytos } \\
\text { (Thessaloniki Prefecture) }\end{array}$ & 3000 & The first VFCW serving an urbanity [16] \\
\hline 1992 & Thessaloniki & $1,400,000$ & $\begin{array}{l}\text { The first WWTP applying reclaimed wastewater } \\
\text { reuse projects [12] }\end{array}$ \\
\hline 1994 & Psyttalia & $5,600,000$ & $\begin{array}{l}\text { The largest WWTP in Greece and among the } \\
\text { largest in Europe [13] }\end{array}$ \\
\hline 2003 & Psyttalia & $5,600,000$ & $\begin{array}{l}\text { Operation of the first large-scale biogas unit in } \\
\text { WWTP [14] }\end{array}$ \\
\hline 2007 & Psyttalia & $5,600,000$ & $\begin{array}{l}\text { The first WWTP operating sludge thermal drying } \\
\text { treatment. (Evaporation capacity } 34.4 \mathrm{tn} / \mathrm{h} \text { ) [14] }\end{array}$ \\
\hline 2014 & $\begin{array}{l}\text { DEYA Heraklion Crete } \\
\text { (Finikia) }\end{array}$ & 200,000 & The first WWTP applying MBR process [19] \\
\hline
\end{tabular}

WSP, Waste Stabilization Ponds; VFCW, vertical flow constructed wetland; MBR, Membrane Biological Reactors.

As consequence to the county's alignment with the European Union's Directives and its economic support, Greece presented higher value of percentage of population connected to tertiary wastewater treatment in the year $2015,88 \%$ as compared to $80.1 \%$ of mean value for central European countries (Austria, Belgium, Denmark, Netherlands, Germany, Switzerland, Luxembourg, and United Kingdom) [18], which are considered more technologically advanced in the field of wastewater treatment and economically stronger than Greece (countries economic status is a key aspect closely related to wastewater treatment status [20]). Meanwhile, the international mean value of percentage of population connected to tertiary wastewater treatment in the year 2015 was 59\% (calculated mean of data from 27 countries) [21].

With respect to Greece's milestones, presented in Table 1, Greece presented a delay between applying the appropriate technology and the technology's first application elsewhere, justified by the social-political-economic constraints that needed to be overcome, institutional arrangements, research and development, and technical and economic co-operation that needed to be established first. In North America, natural treatment systems, treating municipal wastewater, started at the end of the 1960s and beginning of the 1970s [22]. In Sweden, biogas has been produced at municipal wastewater treatment plants since the 1960s [23]. Tertiary treatment of municipal wastewater was first introduced in 1962 in the USA by Lutdzack and Ettinger [24]. In the late 1980s, manufacturers who had successfully applied sludge thermal drying technologies in chemical and food industries, transferred existing technologies to sewage sludge [25]. The first such applications are reported in Avonmouth and Countess Wear in England [26], while by 1993 Membrane Biological Reactors (MBR) systems had been reported for use in sanitary application in Europe [27].

\section{Recent Developments and Current Situation}

Today, Greece has a population of approximately 11 million inhabitants, according to the last official census of 2011. The main management model for water and wastewater services in Greece is delegated public management, although more recently some public-private management schemes have been also started to be implemented. In the two biggest cities of Greece (Athens and Thessaloniki), the Greek state delegated two public companies (by a majority) named E.YD.A.P for Athens and E.Y.A.TH. for Thessaloniki. These companies have been listed also in the Greek stock market already for more than 15 years and the Greek state is the main shareholder and, therefore, the President of the Board of Directors and the CEO of both companies are appointed by the government. For cities with more than 10,000 inhabitants, the national law regulating the role and the foundation of Municipal Water and Sewerage Companies was published in 1980. Currently, there are 130 municipality-owned companies, 
named D.E.Y.A. In cities with fewer than 10,000 inhabitants, the management model is usually the direct urbanity public management [28].

According to article 17 of the Urban Wastewater Treatment Directive 91/271/EEC [10], each member state has to prepare every two years the respective Implementation Report, describing the collection, treatment, and disposal of the relevant wastewater data. Based on the most recent report of 2017 , which refers to the year $2014,91 \%$ of the country's population is connected to 254 urban wastewater treatment plants, treating almost $1.74 \times 10^{6} \mathrm{~m}^{3} /$ day. These plants provide secondary biological treatment, with $83 \%$ providing biological nitrogen removal, $57 \%$ providing (additionally) biological phosphorus removal, and 93\% providing (tertiary) wastewater disinfection [29].

In 2012, a National Database was created by the Specific Secretariat for Water (SSW) of the Greek Ministry of Environment and Energy, with the initiative and the support of the European Commission Directorate-General for Regional and Urban Policy. This Database has been upgraded and enriched ever since, presenting all the relevant information content in an advanced Geographical Information System (GIS), easily accessed by everyone interested via the respective webpage ("SSW-Wastewater Treatment Plants") [30]. Within the Database, specific information regarding the location, capacity, performance, means of disposal, or reuse of wastewater and of sludge, as well as the Environmental Terms of each WWTP are stored and are easily publicly accessible. Figure 3 represents the map of Greece's WWTPs, as presented on SSW webpage, with the respective locations. In this figure there are WWTPs in compliance with the requirements of the Directive 91/271/EEC, as indicated by blue dots (which are representing the majority, i.e., 168 out of 254). The figure presents the WWTPs that are not still compliant with the Directive, either because they do not collect a sufficient number of samples per year, or because the effluent is outside of the respective limits as set by the Directive, which are indicated by red in color dots. Each dot size is logarithmically related to the capacity of each WWTP [31].

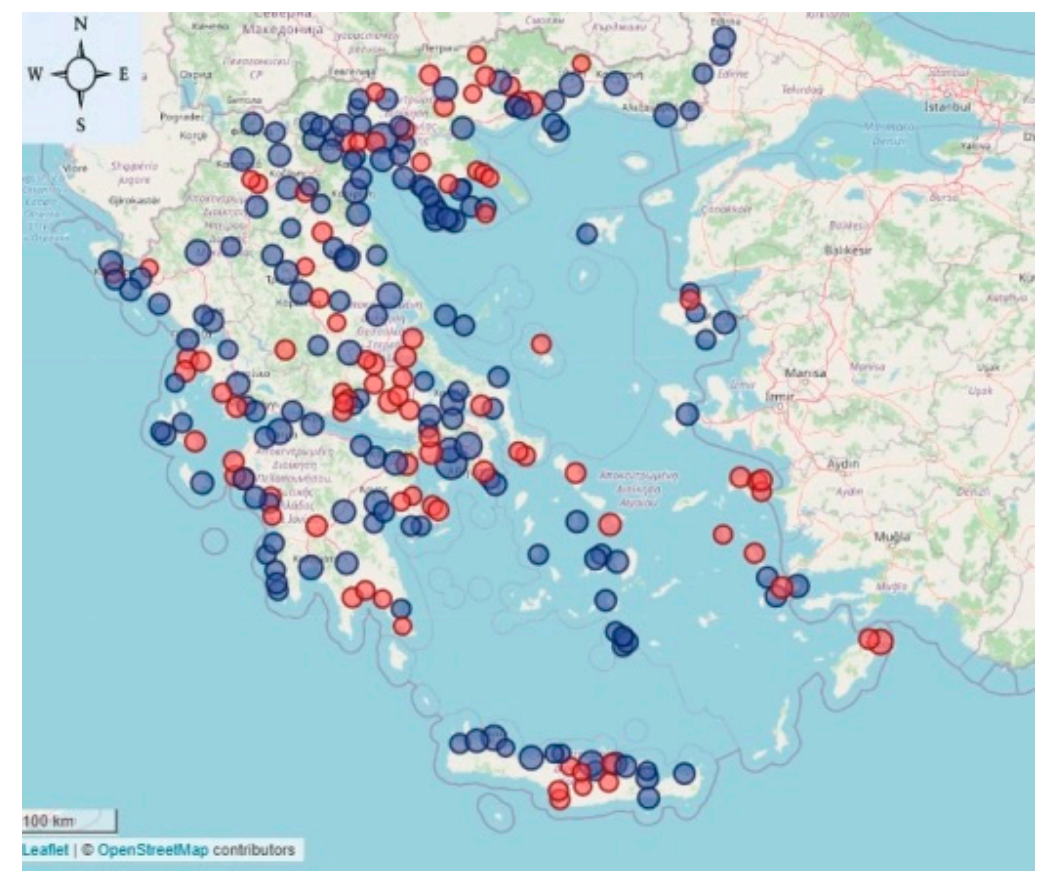

Figure 3. Map of Greece's WWTPs.

Despite the aforementioned developments, EU Commission has brought Greece several times to the EU Court of Justice for violating Directive 91/271/EEC requirements, regarding specific cases. The first condemn took place in 2004 [32], and the Court ruled that Greece was violating EU law by not adequately collecting and treating wastewater discharged into the Gulf of Elefsis, which is characterized as a sensitive area. Twelve years later, the judges ruled that Greece continued to be 
in violation of the previous 2004 ruling, by not taking the "measures necessary for the installation of a collecting system for the urban wastewaters from the Thriasio Plain, in western Attica and not subjecting the urban wastewater from that area to more stringent treatment than the secondary one, before discharged into the sensitive area of the Gulf of Elefsis", imposing a fine of EUR 5 million, with an additional penalty of EUR 3.28 million for every six months the government fails to meet the required wastewater treatment regulations [33].

In 2007, the Court found that Greece had failed to fulfil its obligations on the grounds that 23 urban agglomerations of over 15,000 p.e. were still not equipped with the appropriate systems for collecting and/or treating the urban wastewaters [34]. In 2014, the court found that Greece had still not complied with the previous 2007 judgment in 6 out of the 23 agglomerations, imposing a fixed sum of EUR 10 million and a sliding-scale periodic fine of EUR 20,000 €/day [35]. For the aforementioned fines Greece had to pay EUR 10,558,145 in the year 2019.

Regarding the urban agglomerations between 2000 and 10,000 p.e., the main issues that Greece has to phase is that of the 385 agglomerations belonging in this category, as there are only 123 in full compliance with the requirements of the Directive 91/271/EEC. Another 162 have included or are in the current projects of the National Strategic Reference Framework (NSRF). If these projects are implemented and functioning properly (noting that neither of them is obvious), then in few years the coverage rate will rise to $74 \%$ from today's $32 \%$. The rest of these settlements have some infrastructure missing, have several operational problems, or have incomplete measurements taken and, therefore, they are not shown to meet the rather strict Directive requirements. In order to promote the respective wastewater infrastructures of this category, Greece, with the encouragement of the European Commission, set up in 2018 a committee to design and implement a united national wastewater infrastructure master plan, consisting of 13 regional plans, one for each first-level administrative region of the country. Results of this initiative will soon be published [36].

Agglomerations of less than 2000 inhabitants are accounting for almost 2.5 million p.e. in Greece; in these cases, neither sewage networks nor wastewater treatment are legally enforced [37]. However, there are several natural systems in operation for the treatment of wastewater from small communities, although there is no formal registry of these systems and a detailed reference is quite difficult to be provided, as the relevant references are mainly based on literature review. Waste Stabilization Ponds (WSP) are not so popular in Greece. It is estimated that approximately 20 such systems have been constructed in Greece, serving either single small communities, or two to three neighboring communities being in the range of 600-3000 p.e. The majority of these systems exist in two Prefectures of North Greece (Kavala and Serres). All these systems consist of a primary facultative pond, followed by one to three maturation ponds. Nevertheless, most of these ponds present several operation and maintenance problems, such as odors, rooted plants, etc. [15].

Not more than 20 are the literature-referenced CWs that are currently in operation in Greece, with a capacity between 8-1300 p.e. The majority of these systems consist of one to three vertical subsurface flow (VSSF) beds for primary treatment, one to two VSSF beds for secondary treatment, and one to two beds of horizontal subsurface flow (HSSF) for tertiary treatment; disinfection is performed either by means of UV or chlorination. However, CWs systems that use only free water surface systems (FWS) or HSSF in their configuration are also in operation [38,39].

For the majority of wastewaters that originate from small villages, as well as from the lots of decentralized holiday residences in Greece, septic tanks/soil absorption systems remain as the predominant option for sewage treatment. However, the exact number of these systems is still unknown, since they are seldom formally registered. 


\section{Outlook}

\subsection{Remaining Gaps and Future Challenges}

Greece's wastewater sector has achieved undoubtable progress in terms of infrastructure, technology, and policy implementation, providing a solid ground for its future development. However, in order to be sustainable in this future, providing that wastewater quantity will continue to increase further and that water shortages will become more common [40], specific focus should be provided to the following main objectives:

- Treated wastewater reuse

- $\quad$ Sludge disposal

- $\quad$ Energy efficiency

- $\quad$ Reducing greenhouse emissions

- Management of wastewaters from small settlements that still use quite extensively the septic tanks option

\subsubsection{Treated Wastewater Reuse}

In a 2018 report, the EU Joint Research Center (JRC) projected an increased pressure on water resources of $20 \%$ or more by 2050 , as compared to 2010 in Greece [40]. As all southern European countries are expected to face decreasing water availability, the EU initiated the development of a proposal for the regulation of minimum quality requirements for (treated) wastewater reuse, mainly for agricultural irrigation and/or in the industrial sector. The regulation that is expected to be published in the Official Journal of the EU during 2020 will enter into force on the 20th day after its publication and shall apply to the member states three years after the date of its entry into force. According to estimations, the proposed regulation could lead to a substantial increase of water reuse in agricultural irrigation up to 6.6 billion $\mathrm{m}^{3}$ /year across EU member states, as compared to estimated current 1.7 billion $\mathrm{m}^{3} /$ year in the absence of any EU legal framework [41].

This regulation proposes less strict microbial standards in terms of E. coli, than the maximum value of $200 \mathrm{cfu} / 100 \mathrm{~mL}$ that is currently legally enforced in Greece for unrestricted irrigation (i.e., applicable to all kind of crops, independent from the irrigation method, where public access may also be allowed). The regulation has no provisions for the maximum permissible concentrations of selected heavy metals and metalloids, as well as for certain agronomic characteristics of the reclaimed water for agricultural irrigation, provided by the Greek relevant regulations [42,43]. In that sense, it might set a new perspective on the issue of reclaimed water reuse in the country.

However, it lacks to address other issues that concern Greece's reclaimed water reuse, such as transportation expenses, due to the fact that most WWTPs are located quite far away from arable agricultural land, which poses another economical challenge for the reclaimed wastewater management in Greece [44]. This explains why the reclaimed water reuse for agricultural irrigation is practiced in only $13 \%$ of the existing WWTPs in Greece. The main WWTP of Athens, for instance, located on the Psytalia island, reuses onsite part of its effluent that undergoes filtration (through sand-filters) and disinfection (by means of UV devices), so as to be reused as process water for the treatment facilities [14]. Meanwhile, it is estimated that almost 18,000 ha are being irrigated by the several agricultural water reuse projects in Greece, whereas almost 60,000 more ha are irrigated via the indirect wastewater reuse. As Greece's irrigated land sums up to almost 103,860,000 ha/year [45], there is a huge potential for turning to reclaimed wastewater, rather than using freshwater to cover the needs of the agricultural land, providing that all the necessary concerns regarding human health and environmental protection are met. 


\subsubsection{Sludge Disposal}

Based on the most recent published data, the disposal situation of wastewater sludge from Greece's WWTPs is presented in Figure 4 [46]. In 2016, the sludge production was at the level of 119,770 tones, with the majority of it (53\%) ending up in landfills, 33\% used in agriculture, and only 18\% used for composting or other specific applications, such as alternative fuel in cement industries.

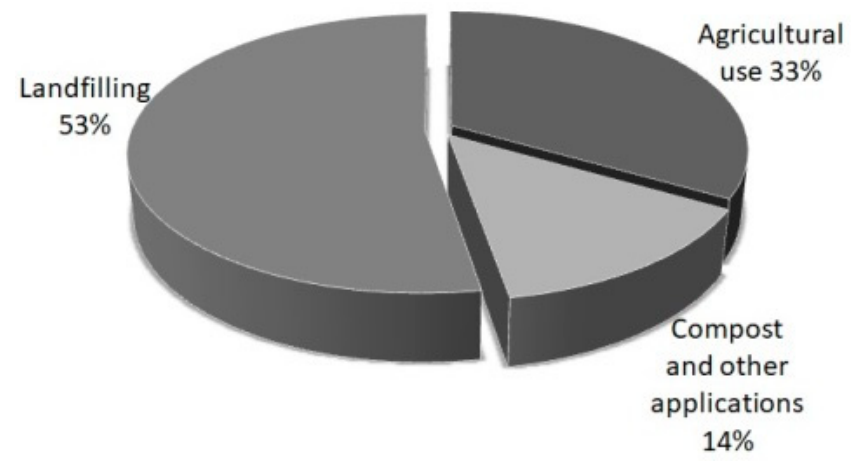

Figure 4. Disposal situation of wastewater sludge from Greece's WWTPs in 2016.

Even though Directive 86/278/EEC, the so-called Sewage Sludge Directive [47], was adopted in Greek legislation back in 1986, aiming to encourage the application of sewage sludge in agriculture and to regulate appropriately its use, attempting to prevent any harmful environmental and human effects, nevertheless the current use of WWTPs sludge for land application is rather limited. This is mainly due to the fact that sludge produced through successive anaerobic digestion/stabilization, dewatering, and thermal drying in the megacities (Athens, Thessaloniki) has a fairly higher heavy metal content [48], than the thresholds of the Ministerial Decision 80568/4225/91 [49], which set supplementary national thresholds for the chromium species $\mathrm{Cr}$ (III) $\left(500 \mathrm{mg} \mathrm{kg}^{-1}\right)$ and $\mathrm{Cr}(\mathrm{VI})\left(10 \mathrm{mg} \mathrm{kg}^{-1}\right)$, apart from the limits of other metal contents as stipulated by Directive 86/278/EEC [50]. For this reason, the dried sludge from the bigger treatment plants is potentially used as a fuel substitute in the cement industry, but also (partly) as soil conditioner.

According to the National Plan on Waste Management (CMA 49/15.12.2015/GG174A) [51] and in accordance to the Directive 2008/98 on waste [43]), the sludge disposal to landfill should be minimized to $5 \%$ by 2020 , while the recovery should be $95 \%$ (energy recovery and agricultural use). In this context, few WWTPs have invested also in Bio-augmentation technology projects that may reduce substantially the sludge, produced in the treatment facilities, by $50 \%-80 \%$ [52]. As such projects are quite limited, there is still scope in Greece for further alignment in order to achieve a sustainable sludge disposal strategy.

\subsubsection{Energy Efficiency}

Energy is a key factor in achieving sustainability in the WWTPs sector, and a shift from the negative energy balance (i.e., when energy demand is being covered by external sources) to the energy neutral, or even to energy positive, wastewater treatment has been postulated worldwide [53].

Biogas produced at Psyttalia WWTP is being utilized onsite as the fuel in two Combined Heat and Power (CHP) plants, of 11.4 MW power capacity. The CHP plant system provides a considerable part of the heat needs of Psyttalia WWTP (especially for sludge digestion and drying), as well as for the electric power needs (e.g., for aeration in biological treatment step), whereas the surplus power is being sold to the National Power Grid Manager [14]. Meanwhile, the plant continues to participate in innovative projects that would further enhance its energy efficiency. The SMARTech $4 \mathrm{~b}$ pilot scale system (part of the ongoing SMART-Plant project, funded under European Union's Horizon 2020 research and innovation program) will be tested and validated at the WWTP of Psyttalia, aiming to enable the integration of enhanced biogas recovery (by preliminary thermal hydrolysis) of sewage 
sludge with side-stream, energy-efficient, and compact nitrogen removal and phosphorus recovery, avoiding the problematic struvite formation [54].

Meanwhile, other research programs are ongoing at smaller WWTPs in Greece. e.g., the LIFE B2E4 sustainable-WWTP project (funded by the European Commission under the LIFE Framework Programme) [55] aims to improve the performance of overloaded extended aeration wastewater treatment plants, by using a novel process for removing solids prior to aeration. For this purpose, a micro-screening system for the removal of oversized solids will be installed at DEYA's WWTP, serving the Rethymno area of Crete Island (located in the southern part of Greece). The plant, which applies an extended aeration activated sludge process, has an average daily flow of 13,000 to $15,000 \mathrm{~m}^{3}$. Its peak flow capacity is about $17,000 \mathrm{~m}^{3} /$ day. In addition, the project will demonstrate the valorization of produced biosolids for the production of electric energy (mainly through gasification), thus reducing further the net energy consumption of the WWTP. The produced electric energy will be sufficient for energy self-sustainable operation for wastewater treatment. According to theoretical estimations, waste heat from the plant itself can provide energy to $10 \%$ of the buildings that deliver wastewater to the WWTP [56].

Even though there is no specific national or EU legislation to be followed for improving the overall energy performance of WWTPs, with the majority of plants built more than 20 years ago in Greece, the opportunity of promoting the energy efficient wastewater resource recovery concept-through technological improvements within the existing plants to transform the wastewater treatment plants into real power producers (i.e., prosumers, instead of consumers) and to eventually prompt the development of new products and business opportunities-is another challenge for the wastewater treatment sector that Greece cannot overlook.

\subsubsection{Reducing Greenhouse Emissions}

Improving energy efficiency in urban wastewater facilities can help reduce Green House Gas (GHG) emissions from the WWTPs, where GHG are largely in the form of carbon dioxide $\left(\mathrm{CO}_{2}\right)$, methane $\left(\mathrm{CH}_{4}\right)$, and nitrous oxide $\left(\mathrm{N}_{2} \mathrm{O}\right) . \mathrm{CO}_{2}$ is mainly produced during the applied wastewater and sludge treatment processes, as well as through the consumption of energy during WWTPs' operation [57]. $\mathrm{CH}_{4}$ is mostly emitted during the sludge treatment works (e.g., sludge anaerobic digestion, sludge disposal to landfills), while it can also leak from the biogas plants (due to poor design or maintenance), and $\mathrm{N}_{2} \mathrm{O}$ can be emitted during the biological processes, aiming toward nitrogen removal [58]. $\mathrm{CO}_{2}$ is not accounted as GHG from WWTPs' operation, due to its biogenic origin, whereas the main focus is directed to $\mathrm{CH}_{4}$ and $\mathrm{N}_{2} \mathrm{O}$ gases, which present a global warming potential 28 and 265 times higher, respectively, than the $\mathrm{CO}_{2}$, considering a 100-year period [59].

Greece, as an EU member state, has committed to a 40\% GHG emissions' reduction by 2030, as compared to 1990 levels. Because GHG emissions from the urban wastewater treatment $(0.458$ million tons of the specific $\mathrm{CO}_{2}$ equivalent $\left(\mathrm{CO}_{2} \mathrm{e}\right)$ in 2017, according to Eurostat data, [60]) account for approximately one-fifth of the emissions from the overall waste sector, it remains important to carefully manage $\mathrm{CH}_{4}$ and $\mathrm{N}_{2} \mathrm{O}$ gases and to accomplish the overall GHG emissions targets.

The quantification of GHG emissions from WWTPs in Greece is rather a difficult task, due to unavailable formal registered data and quantifying the models' approach complexity. A recent study reported that the two major WWTPs of Greece (Athens and Thessaloniki) contribute to $67.1 \%$ of the total emitted GHG, as expressed in tones/day of $\mathrm{CO}_{2} \mathrm{e}$. The contribution of WWTPs with capacity ranging between 10,000 and 100,000 inhabitants accounts for $20.6 \%$, while the contribution of the other groups of WWTPs is less than $10 \%$, either due to their small number, or due to the lower volumes of wastewaters, which are treated daily [61].

However, as reported in the literature, GHG emissions depend mainly on the wastewater composition and the applicable treatment technologies and, hence, they are not always linked to the respective treatment plants' capacity (actual loads) [54]. Thus, the focus is devoted to the minimization and prevention rather than the treatment of GHG emissions in WWTPs, as up to now most of the 
technologies available for the treatment of GHG are quite expensive, or even not suitable/effective enough to treat the gaseous streams of WWTPs [62].

Thus, when choosing the configuration of new WWTPs and deciding on how to upgrade the existing (aged) ones, the proper evaluation of the treatment processes should be performed, attempting to lower the contribution towards global warming, being as little as possible. The application of certain models, estimating GHG emissions, could be adopted by the National Database of the SSW (Specific Secretariat for Water) of the Greek Ministry of Environment and Energy, so as to help the operators of treatment systems to reduce GHG emissions from the existing WWTPs. Finally, to enhance this target, a limit value of $\mathrm{CO}_{2} \mathrm{e}$ emission $/ \mathrm{m}^{3}$ of treated wastewater, e.g., $<2 \mathrm{~kg} \mathrm{CO} \mathrm{CO}_{2} \mathrm{e} / \mathrm{m}^{3}$, as recommended by Koutsou et al. [61] (compared to $2.2 \mathrm{~kg} \mathrm{CO} \mathrm{CO}_{2} \mathrm{e} / \mathrm{m}^{3}$ of currently estimated for Greece [47] and to $0.8-1 \mathrm{~kg} \mathrm{CO} \mathrm{CO}_{2} \mathrm{e} / \mathrm{m}^{3}$ of currently estimated for anaerobic/anoxic/oxic treatment processes for urban WWTPs [62]), could be adopted in the national legislation. Note also that the limit value does not have to remain constant over time, but it should be regularly updated in respect to the observed global trends, regarding the GHG emissions from the WWTP sector.

\subsubsection{Management of Wastewater from Small Urban Settlements that Still Use Septic Tanks}

In Greece, there are many agglomerations with less than 2000 inhabitants, which account for almost 2.5 million p.e., where sewerage networks are not legally enforced and where the septic tank/soil absorption systems are the common norm [37].

The Special Secretariat for Water of the Greek Ministry of Environment published in 2012 specific guidelines regarding the wastewater management from small settlements (SSW) [37]. This text provided directions for the onsite wastewater treatment alternatives to the septic tank/soil absorption systems, by codifying the international experience of the existing till then technology making the appropriate adaptations to the country's particularities. Since then, the alternative onsite wastewater treatment technologies and the relevant research have evolved in Greece, e.g., regarding the use of CWs [38], Sequencing Batch Reactors (SBR) [63], or even the Membrane Biological Reactors (MBR systems) [64], and other combinations of treatment techniques, such as MBR-RO (Reverse Osmosis) [65], following the respective international trends on adapting these technologies for the onsite wastewater management and reuse in small settlements [66], as well as for the tourist-based communities [67]. However, neither the existing guidelines of SSW have been revised, nor have the alternative technologies of wastewater management, penetrated in any large extend to solve the problem of not-sewerage areas of Greece, leaving the respective situation practically unchanged.

There is always a concern with respect to the adverse environmental impacts and local public health risks of failing, or inadequately designed septic tank/soil absorption systems, used in the not-sewerage areas of Greece [68]. As such, systems receive an increased load during the holiday seasons (particular in summer, where the population in several small settlements is doubled or even more) and due to the rapid growth of short-term holiday rentals of such type of possible remote residences, especially over the last years [69], and also due to an increasing number of refugees and migrants (especially for certain Aegean islands) [70,71]. The systems may then face water shortage problems [72,73], and where the number of the hosted migrants may raise the native population by one-third or even more [70]. There is an urge that management of wastewater from the small settlements should not be left out of policies, regarding wastewater treatment and wastewater reuse in general, especially in the water-scarce areas of the country. In fact, the public acceptance of reused wastewater as a resource may be gained, if specific attention is driven first to the proper management and reuse of wastewater, produced at such small scale.

A policy reform towards this direction could include: (a) a mandatory registry of each type of wastewater system that is not connected to centralized sewage treatment plants, aiming this registry to serve as a dynamic tool for the authorities for providing directions, instructions, and support, regarding the proper wastewater treatment and reuse, thus upgrading the role of SSW's guidelines; (b) 
support funding for the efficient (residential and small business, e.g., hotels) decentralized wastewater management and reuse projects.

As currently the EU is searching effective ways to emerge from the COVID-19 crisis by injecting the economy with funds [74], the ecological part and the greening of the economy, regarding the onsite decentralized treatment level of wastewaters, should not be overlooked. In fact, a promising area of the ongoing research on COVID-19 involves using sewage to monitor virus circulation in communities and to detect possible outbreaks, even before clinical cases have been identified [75]. In that sense, as novel enveloped viruses are expected to emerge, when leaving homes or staying at decentralized hotels, where proper onsite wastewater management and reuse is applied, this approach could help tackle, at the local scale, and avoid larger-scale virus outbreaks in the future.

The tools and experience gained by e.g., the relevant Greek-EU co-funded "Saving Energy at Home" Programme, a grant and loan program that recently run again in Greece [76], could also help in planning of a relevant program that would ease owners to select and implement the adequate wastewater treatment and reuse technology, without being discouraged by the amount of work, the administrative complexity, and certain technical challenges.

\section{Conclusions}

When reviewing the development history of Greece's wastewater sector, there are both achievements and failures. Even though the country has accomplished its wastewater infrastructure construction to a large extent, many problems are still existing. These include the reuse of treated wastewater and the disposal of produced excess sludge, the remaining high energy consumption of the existing rather aged WWTPs, and the environmental impacts and local public health risks of failing or inadequately designed septic tank/soil absorption systems, still used in the not-sewerage areas of Greece (small settlements, located in mountainous areas or islands), with agglomerations of less than 2000 inhabitants, where sewage networks are not legally enforced.

Looking forward, there will be more challenges in the future, due to the multiple pressures of environment protection, water shortage, economic development (e.g., tourism), or economic crisis. To address these challenges, specific care should be directed to the country's own characteristics and needs, as well as to including global environmental thinking and international technological trends in the development of new policies and the operation of WWTPs, in ways that would promote both resource recovery and environmental sustainability.

Author Contributions: Writing—original draft, C.P.; writing—review and editing, A.Z. All authors have read and agreed to the published version of the manuscript.

Funding: This research received no external funding.

Conflicts of Interest: The authors declare no conflicts of interest.

\section{References}

1. EEA. European Environment Agency: Surface Water Quality Monitoring-Summary: Greece. Available online: https://www.eea.europa.eu/publications/92-9167-001-4/page010.html (accessed on 2 May 2020).

2. Philandras, C.M.; Nastos, P.T.; Repapis, C.C. Air temperature variability and trends over Greece. Glob. NEST J. 2008, 10, 273-285.

3. Chenoweth, J.; Hadjinicolaou, P.; Bruggeman, A.; Lelieveld, J.; Levin, Z.; Lange, M.A.; Xoplaki, E.; Hadjikakou, M. Impact of climate change on the water resources of the eastern Mediterranean and Middle East region: Modeled 21st century changes and implications. Water Resour. Res. 2011, 47, W06506. [CrossRef]

4. Ferronato, N.; Torretta, V. Waste Mismanagement in Developing Countries: A Review of Global Issues. Int. J. Environ. Res. Public Health 2019, 16, 1060. [CrossRef] [PubMed] 
5. Angelakis, A.N.; Spyridakis, S.V. The status of water resources in Minoan times-A preliminary study. In Diachronic Climatic Impacts on Water Resources with Emphasis on Mediterranean Region; Angelakis, A.N., Issar, A., Eds.; NATO ASI Series; Springer: Heidelberg, Germany, 1996; Volume 36, pp. 161-191.

6. Lofrano, G.; Brown, J. Wastewater management through the ages: A history of mankind. Sci. Total. Environ. 2010, 408, 5254-5264. [CrossRef] [PubMed]

7. Andreadakis, A.; Agelakis, T.; Adraktas, D. Treatment and disposal of the waste-water of Thessaloniki, Greece. Environ. Int. 1993, 19, 291-299. [CrossRef]

8. Golfinopoulos, A. The Diachronic Management of Waste in Antiquity in Greece. Bachelor's Thesis, Hellenic Open University, Patra, Greese, 15 March 2016.

9. Historic Overview of Water Supply. Available online: https:/www.eydap.gr/en/TheCompany/Water/ HistoricalTrackBack/ (accessed on 21 March 2020).

10. Directive 91/271/EEC of 21 May 1991 on Urban Waste-Water Treatment 91/271/EEC. Official Journal of the European Communities, Brussels. 1991. 13p. Available online: https://eur-ex.europa.eu/legalcontent/EN/ TXT/PDF/?uri=CELEX:31991L0271\&from=EN (accessed on 21 March 2020).

11. Directive 98/15/EEC of 27 February 1998. Available online: https://eur-lex.europa.eu/LexUriServ/LexUriServ. do?uri=CONSLEG:1998L0015:19980327:EN:PDF (accessed on 21 March 2020).

12. Ilias, A.; Panoras, A.; Angelakis, A. Wastewater Recycling in Greece: The Case of Thessaloniki. Sustainability 2014, 6, 2876-2892. [CrossRef]

13. E.YD.A.P Wastewater Treatment. Available online: https://www.eydap.gr/TheCompany/ DrainageAndSewerage/Sewerage/ (accessed on 21 March 2020).

14. E.YD.A.P Psyttalia Wastewater Treatment Plant. Available online: https://www.eydap.gr/userfiles/c3c4382da658-4d79-b9e2-ecff7ddd9b76/Fact-sheet-PWWTP.pdf (accessed on 21 March 2020).

15. Kotsovinos, N.; Tsagarakis, K.P.; Tsakiris, K.; Agricultural, N. Waste stabilization ponds in Greece: Case studies and perspectives. In Proceedings of the 6th International Conference on Waste Stabilisation Ponds, Avignon, France, 28 September-1 October 2004; IWA: London, UK.

16. Gikas, G.D.; Tsihrintzis, V.A. Urban wastewater treatment using constructed wetlands. Water Util. J. 2014, $8,57-65$.

17. Tsagarakis, K.P.; Mara, D.D.; Horan, N.J.; Angelakis, A.N. Small urban wastewater treatment plants in Greece. Water Sci. Technol. 2000, 41, 41-48. [CrossRef]

18. Changes in Urban Waste Water Treatment in Southern Europe. Available online: https://www.eea. europa.eu/data-and-maps/daviz/changes-in-wastewater-treatment-in-10\#tab-dashboard-01 (accessed on 21 March 2020).

19. Wastewater Treatment Plant in Finikia is in Operation. Available online: https://www.heraklion.gr/ municipality/press-releases-2014/se-leitourgia-h-monada-epexergasias-apovlhtwn-22082014.html (accessed on 10 July 2020). (In Greek)

20. Sato, T.; Qadir, M.; Yamamoto, S.; Endo, T.; Zahoor, A. Global, regional, and country level need for data on wastewater generation, treatment, and use. Agric. Water Manag. 2013, 130, 1-13. [CrossRef]

21. Wastewater Treatment (\%) Population Connected. OECD Srat. Available online: https://stats.oecd.org/Index. aspx?DataSetCode=WATER_TREAT (accessed on 27 July 2020).

22. Naja, G.; Volesky, B. Constructed Wetlands for Water Treatment. Compr. Biotechnol. 2011, 6, 353-369. [CrossRef]

23. Eriksson, O.; Bisaillon, M.; Haraldsson, M.; Sundberg, J. Improvements in Environmental Performance of Biogas Production from Municipal Solid Waste and Sewage Sludge. In Proceedings of the World Renewable Energy Congress, Linköping, Sweden, 8-13 May 2011; Linkoping University Electronic Press: Linköping, Sweden, 2011; Volume 57, pp. 3193-3200.

24. Ludzack, F.J.; Ettinger, M.B. Controlling operation to minimize activated sludge effluent nitrogen. J. Water Pollut. Control Fed. 1962, 34, 920-931.

25. Chen, G.; Yue, P.L.; Mujumdar, A.S. Sludge Dewatering and Drying. Dry. Technol. 2002, 20, 883-916. [CrossRef]

26. Hudson, J.A. Treatment and Disposal of Sewage Sludge in the Mid-1990s. Water Environ. J. 1995, 9, 93-100. [CrossRef]

27. Aya, H. Modular membranes for self contained reuse systems. Water Qual. Int. 1994, 21, 128-136. 
28. Renou, Y. The Governance of Water Services in Developing Countries: An Analysis in Terms of Action Stratification. J. Econ. Issues 2010, 44, 113-138. [CrossRef]

29. European Commission. Ninth Report on the Implementation Status and the Programmes for Implementation (As Required by Article 17) of Council Directive 91/271/EEC Concerning Urban Waste Water Treatment; Report: COM (2017) 749 Final; European Commission: Brussels, Belgium, 2018; 18p.

30. SSW. Wastewater Treatment Plants. Available online: http://astikalimata.ypeka.gr/Services/Pages/ WtpViewApp.aspx (accessed on 21 March 2020).

31. Map of Greece's WWTPs. Available online: http://astikalimata.ypeka.gr/Services/Pages/WtpViewApp.aspx (accessed on 21 March 2020).

32. EU Court of Justice. Judgement No. C-119/02 of 24 June 2004. Available online: https://op.europa. eu/en/publication-detail/-/publication/5f3eaad5-3180-423a-806c-f091d7a5ba60/language-en (accessed on 21 March 2020).

33. EU Court of Justice. Judgement No. C-328/16 of 22 February 2018 . Available online: https://op.europa.eu/en/publication-detail/-/publication/09a5d1a1-4149-11e8-b5fe-01aa75ed71a1/ language-en/format-PDF/source-120866608 (accessed on 21 March 2020).

34. EU Court of Justice. Judgement No. C-440/06 of 25 October 2007. Available online: https://op.europa. eu/en/publication-detail/-/publication/46d1f9fc-c804-4301-811c-e70e5d62dbd7/language-en (accessed on 21 March 2020).

35. EU Court of Justice. Judgement No. C-167/14 of 15 October 2015. Available online: https://op.europa.eu/en/ publication-detail/-/publication/ddfaac60-9cb3-11e5-b792-01aa75ed71a1/language-en/format-PDF (accessed on 21 March 2020).

36. Lalios, G. Fewer than Half the Small Greek Cities with Sewage Network. Available online: https://www.kathimerini.gr/1017094/article/epikairothta/ellada/ligoteres-apo-tis-mises-oi-mikresellhnikes-poleis-me-apoxeteysh (accessed on 21 March 2020).

37. SWW. Guidelines Text for Wastewater Management of Small Settlements. Available online: http: //www.ypeka.gr/LinkClick.aspx?fileticket=0yUWZWCWi3s\%3d\&tabid=251\&language=el-GR (accessed on 21 March 2020).

38. Lavrnić, S.; Mancini, M.; Lavrni, S. Can constructed wetlands treat wastewater for reuse in agriculture? Review of guidelines and examples in South Europe. Water Sci. Technol. 2016, 73, 2616-2626. [CrossRef]

39. Zouboulis, A.; Prochaska, C.; Angelakis, A. Constructed wetlands wastewater treatment plants and agricultural reuse status in Greece. Presented at the ISCW 2019, Patras, Greece, 29-31 August 2019.

40. Bisselink, B.; Bernhard, J.; Gelati, E.; Adamovic, M.; Guenther, S.; Mentaschi, L.; De Roo, A. Impact of a Changing Climate, Land Use, and Water Usage on Europe's Water Resources; EUR 29130 EN; Publications Office of the European Union: Luxembourg, 2018.

41. European Commission. Proposal for a Regulation of the European Parliament and of the Council on Minimum Requirements for Water Reuse; Report: COM (201)337/975937; European Commission: Brussels, Belgium, $2018 ; 28$ p.

42. CMD (Common Ministerial Decision). Measures, Limits and Procedures for Reuse of Treated Wastewater; Number 145116; Energy and Climate Change; Ministry of Environment: Athens, Greece, 2011. (In Greek)

43. CMD (Common Ministerial Decision). Amendment of CMD 145116 Measures, Limits and Procedures for Reuse of Treated Wastewater; Number 191002; Energy and Climate Change; Ministry of Environment: Athens, Greece, 2013. (In Greek)

44. Angelakis, A.N.; Asano, T.; Bahri, A.; Jiménez, B.E.; Tchobanoglous, G. Water Reuse: From Ancient to Modern Times and the Future. Front. Environ. Sci. 2018, 6, 1-17. [CrossRef]

45. Statistics-ELSTAT. B03. Holdings with Irrigable and Irrigated Areas, by Region and Department Excel File. Available online: http://www.statistics.gr/en/statistics/-/publication/SPG31 (accessed on 21 March 2020).

46. Statistics-EUROSTAT. Sewage Sludge Production and Disposal from Urban Wastewater (in Dry Substance (d.s)). Available online: https://ec.europa.eu/eurostat/databrowser/view/ten00030/default/table?lang=en (accessed on 21 March 2020).

47. Directive 86/278/EEC of the 4 July 1986. On the Protection of the Environment and in Particular of the Soil When Sewage Sludge is Used in Agriculture. Available online: https://eur-lex.europa.eu/legal-content/EN/ TXT/?uri=celex\%3A31986L0278 (accessed on 21 March 2020). 
48. Spanos, T.; Ene, A.; Patronidou, C.S.; Xatzixristou, C. Temporal variability of sewage sludge heavy metal content from Greek wastewater treatment plants. Ecol. Chem. Eng. S 2016, 23, 271-283. [CrossRef]

49. Ministerial Decision: Greek Legislation 80568/4225/91 of 22 March 1991 on Methods, Specifications and Requirements for the Use in Agriculture of the Sludge Originating from Household and Urban Waste Treatment, Harmonized from European Council Directive; 86/278/EEC; Official Government Gazette of the Hellenic Republic: Athens, Greece, 1991.

50. CMA (Council of Ministers Act) 49 of 15-12-2015 (Government Gazette 174/A/15-12-2015); Official Government Gazette of the Hellenic Republic: Athens, Greece, 2015. (In Greek)

51. Directive 2008/98/EC of 19 November 2008. On Waste. Available online: https://eur-lex.europa.eu/legalcontent/EN/TXT/?uri=CELEX:32008L0098 (accessed on 21 March 2020).

52. Bio-Augmentation for the Sludge Reduction in the WWTP of Patras, Greece. Available online: https://alphabioenergy.com/project/bio-augmentation-for-the-sludge-reduction-in-the-wwtp-of-patras-greece/ (accessed on 26 March 2020).

53. Gao, H.; Scherson, Y.D.; Wells, G.F. Towards energy neutral wastewater treatment: Methodology and state of the art. Environ. Sci. Process. Impacts 2014, 16, 1223-1246. [CrossRef]

54. SMART-Plant Project. European Union's Horizon 2020 Grant No. 690323. Available online: https: //www.smart-plant.eu/index.php/psyttalia (accessed on 26 March 2020).

55. Biosolids2Energy Research Project (LIFE LIFE16 ENV/GR/000298). Available online: http://www. biosolids2energy.eu/home.html (accessed on 26 March 2020).

56. Tolkou, A.K.; Zouboulis, A.; Samaras, P. Energy and Wastewater Treatment Plants. In Sustainability behind Sustainability; Zorpas, A., Ed.; Nova Science Publisher: Hauppauge, NY, USA, 2014; pp. 1-48.

57. Mamais, D.; Noutsopoulos, C.; Dimopoulou, A.; Stasinakis, A.; Lekkas, T.D. Wastewater treatment process impact on energy savings and greenhouse gas emissions. Water Sci. Technol. 2014, 71, 303-308. [CrossRef]

58. Massara, T.M.; Malamis, S.; Guisasola, A.; Baeza, J.A.; Noutsopoulos, C.; Katsou, E. A review on nitrous oxide (N2O) emissions during biological nitrogen removal from urban wastewater and sludge reject water. Sci. Total Environ. 2017, 596-597, 106-123. [CrossRef] [PubMed]

59. Intergovernmental Panel on Climate Change. Climate Change 2013: The Physical Science Basis; Working Group I Contribution to the IPCC 5th Assessment Report; IPCC: New York, NY, USA, 2013.

60. Statistics-EUROSTAT. Greenhouse Gas Emissions by Source Sector. Domestic Wastewater; Code: CRF5D1. Available online: https://appsso.eurostat.ec.europa.eu/nui/submitViewTableAction.do (accessed on 26 March 2020).

61. Koutsou, O.P.; Gatidou, G.; Stasinakis, A. Domestic wastewater management in Greece: Greenhouse gas emissions estimation at country scale. J. Clean. Prod. 2018, 188, 851-859. [CrossRef]

62. Nguyen, T.K.L.; Ngo, H.H.; Guo, W.; Chang, S.W.; Nguyen, D.D.; Nghiem, L.D.; Liu, Y.; Ni, B.; Hai, F.I. Insight into greenhouse gases emissions from the two popular treatment technologies in urban wastewater treatment processes. Sci. Total Environ. 2019, 671, 1302-1313. [CrossRef]

63. Kornaros, M.; Marazioti, C.; Lyberatos, G. A pilot scale study of a sequencing batch reactor treating urban wastewater operated via the UP-PND process. Water Sci. Technol. 2008, 58, 435-438. [CrossRef]

64. Malamis, S.; Andreadakis, A.; Mamais, D.; Noutsopoulos, C. Can strict water reuse standards be the drive for the wider implementation of MBR technology? Desalin. Water Treat. 2015, 53, 3303-3308. [CrossRef]

65. Plevri, A.; Mamais, D.; Noutsopoulos, C.; Makropoulos, C.; Andreadakis, A.; Rippis, K.; Smeti, E.; Lytras, E.; Lioumis, C. Promoting on-site urban wastewater reuse through MBR-RO treatment. Desalin. Water Treat. 2017, 91, 2-11. [CrossRef]

66. Capodaglio, A.G.; Callegari, A.; Cecconet, D.; Molognoni, D. Small Communities Decentralized Wastewater Treatment: Assessment of Technological Sustainability. In Proceedings of the 13th IWA Specialized Conference on Small Water and Wastewater Systems \& 5th IWA Specialized Conference on Resources-Oriented Sanitation, Athens, Greece, 14-17 September 2016.

67. Santana, M.V.; Cornejo, P.K.; Rodríguez-Roda, I.; Buttiglieri, G.; Corominas, L. Holistic life cycle assessment of water reuse in a tourist-based community. J. Clean. Prod. 2019, 233, 743-752. [CrossRef]

68. Gikas, P.; Ranieri, E.; Sougioultzis, D.; Farazaki, M.; Tchobanoglous, G. Alternative collection systems for decentralized wastewater management: An overview and case study of the vacuum collection system in Eretria town, Greece. Water Pr. Technol. 2017, 12, 604-618. [CrossRef] 
69. Boutsioukis, G.; Fasianos, A.; Petrohilos-Andrianos, Y. The spatial distribution of short-term rental listings in Greece: A regional graphic. Reg. Stud. Reg. Sci. 2019, 6, 455-459. [CrossRef]

70. Koka, E.; Veshi, D. Irregular Migration by Sea: Interception and Rescue Interventions in Light of International Law and the EU Sea Borders Regulation. Eur. J. Migr. Law 2019, 21, 26-52. [CrossRef]

71. Tsartas, P.; Kyriakaki, A.; Stavrinoudis, T.; Despotaki, G.; Doumi, M.; Sarantakou, E.; Tsilimpokos, K. Refugees and tourism: A case study from the islands of Chios and Lesvos, Greece. Curr. Issues Tour. 2019, 23, 1311-1327. [CrossRef]

72. Kaldellis, J.; Kondili, E. The water shortage problem in the Aegean archipelago islands: Cost-Effective desalination prospects. Desalination 2007, 216, 123-138. [CrossRef]

73. Stathatou, P.M.; Gad, F.K.; Kampragou, E.; Grigoropoulou, H.; Assimacopoulos, D. Treated wastewater reuse potential: Mitigating water scarcity problems in the Aegean islands. Desalin. Water Treat. 2014, 53, 3272-3282. [CrossRef]

74. EU Leaders Clash over Trillion-Euro Covid-19 Aid in Online Meeting. Available online: https://www.theguardian.com/world/2020/apr/23/clashes-predicted-over-trillion-euro-covid-19-aidas-eu-meets-online (accessed on 24 April 2020).

75. Wigginton, K.R.; Boehm, A.B. Environmental Engineers and Scientists Have Important Roles to Play in Stemming Outbreaks and Pandemics Caused by Enveloped Viruses. Environ. Sci. Technol. 2020, 54, 3736-3739. [CrossRef] [PubMed]

76. Save Energy at Home Greece-CA EED. Available online: www.ca-eed.eu (accessed on 24 April 2020).

(C) 2020 by the authors. Licensee MDPI, Basel, Switzerland. This article is an open access article distributed under the terms and conditions of the Creative Commons Attribution (CC BY) license (http://creativecommons.org/licenses/by/4.0/). 